\title{
UNESCO's tangible and intangible cultural heritage: Sustainable development perspectives
}

\author{
Elena Sinibaldi, Antonio Parente
}

For citation: Sinibaldi, Elena, Parente, Antonio. 2020. UNESCO's tangible and intangible cultural heritage: Sustainable development perspectives. Pravovedenie 64 (1): 47-56.

https://doi.org/10.21638/spbu25.2020.104

\begin{abstract}
The United Nations Educational, Scientific and Cultural Organization (UNESCO) 2003 Convention for the Safeguarding of the Intangible Cultural Heritage has not only introduced a conceptual and applicative expansion of the interdisciplinary subjects applied to cultural heritage, but it has also increasingly encouraged an integrated planning of sustainable development policies for territories and communities that convey and shape their relative cultural and anthropomorphic identity, along with the re-thinking of the collective dimension of heritage in terms of rights to creation and fruition as well as the related cultural management. This article presents a reflection on the opportunity to identify and develop the relationship between tangible and intangible heritage as resources that are essential to one another. To this purpose, two illustrative UNESCO application paths are examined. The first relates to the recognition of The Vineyard Landscape of Piedmont: Langhe-Roero and Monferrato as a Cultural Landscape of World Heritage, pursuant to the 1972 UNESCO Convention Concerning the Protection of the World Cultural and Natural Heritage, while the second concerns the inscription of the intangible element The Celebration of Celestinian Forgiveness in the Representative List of the Intangible Cultural Heritage of Humanity of the UNESCO 2003 Convention. Due to differences in paradigms and application criteria under the two UNESCO Conventions, which are also detectable in the Italian regulatory context, these case studies offer the opportunity to advance an interdisciplinary reflection aimed at rethinking safeguarding contexts, as well as enhancement and increasing accessibility of cultural heritage. As a result of the reflection, an analysis of the concept of living in relation to the anthropological definition of organic landscape, representation of collective identities (community-based heritage), inclusive places and sociability (public policy), communicative restitution (universal ethical values), participatory management (participative brand making), and integrated sustainability is derived.
\end{abstract}

Keywords: UNESCO, tangible cultural heritage, intangible cultural heritage, sustainable development, cultural collective rights, benefit sharing.

The concept of intangible cultural heritage $(\mathrm{ICH})$ emerges in relation to the sense of identity, memory and continuity of communities, groups and individuals, since the owners of $\mathrm{ICH}$ values are dynamic actors, transmitting and renewing the values throughout time. As declared in article 1 of the 2003 UNESCO Convention for the Safeguarding of the Intangible Cultural Heritage, the safeguarding of $\mathrm{ICH}$ is among the main purposes of the Convention ${ }^{1}$. The first part of this paper will address the basic concepts of UNESCO's

Elena Sinibaldi - PhD, Ministry for Cultural Heritage and Activities and for Tourism, 27, Via del Collegio Romano, Rome, 00186, Italy; elena.sinibaldi@beniculturali.it

Antonio Parente - Dr. Sci. in Law, Lawyer, Ministry for Cultural Heritage and Activities and for Tourism, 27, Via del Collegio Romano, Rome, 00186, Italy; antonio.parente@beniculturali.it

1 Official text is available on the UNESCO website. Available at: https://ich.unesco.org/en/convention (accessed: 21.08.2020).

(c) St. Petersburg State University, 2021 
2003 Convention (such as safeguarding, tradition, creativity and $\mathrm{ICH}$ itself) in terms of integrated sustainability (social, economic, environmental, cultural); the second part, indeed, is dedicated mostly to two key studies (from Italy) as well as a theoretical approach regarding the relationship between tangible and intangible heritage.

Safeguarding is part of a complex cultural process that involves different stakeholders and institutions. The largest participatory system includes communities, nongovernmental organizations (NGOs), institutions, media, and civil society. Safeguarding, indeed, is based on community involvement, and is linked with different processes that start from the identification and definition of $\mathrm{ICH}$, documentation, formal and non-formal transmission, revitalization, promotion and management ${ }^{2}$. Safeguarding without freezing cultural heritage, as recommended by the United Nations Educational, Scientific and Cultural Organization (UNESCO), merges two apical aspects of the cultural expression: tradition and creativity. Of course, tradition is connected to the past and crosses generations while also being varied and partly recreated over time and maintaining its viability in the present day. Creativity, in turn, is one of the bases of cultural diversity, and it provides a direct tool for involving young people, new generations and civil society, at large, in the safeguarding process. Moreover, it permits the development of intergenerational and intercultural dialogue.

$\mathrm{ICH}$ is intrinsically dynamic and multifaceted, dense with a variety of customary practices that have specific aspects, so that there cannot be a single standard way of managing it. The complexity of a safeguarding system cannot neglect the gist of the social value of $\mathrm{ICH}$, which is essentially cultural, and which cannot be directly translated into a commercial value. In fact, the direct economic value resulting from the consumption and trade of $\mathrm{ICH}$ products is only one aspect, and it is not the most relevant one, since the most significant value of $\mathrm{ICH}$, as clearly remarked in the UNESCO documents ${ }^{3}$, resides in community identity and continuity, which are aimed at social cohesion and without which development would be impossible.

The United Nations (UN) 2030 Sustainable Development Agenda (already accepted into the decision 10.COM 14.a of the Intergovernmental Committee for the Safeguarding of the Intangible Cultural Heritage and the resolution 6.GA 7 of the General Assembly for the UNESCO 2003 Convention) remarks on the socially-inclusive approach that looks at the society-of-the-future and specifies the balance of the three integrated dimensions of sustainable development: economic, social and environmental ${ }^{4}$. This approach to future economic growth pays due attention to people-centric approaches for sustainability, without discriminating against any groups such as vulnerable or disabled people, children, women, young people, indigenous people, refugees, internally displaced persons and migrants. The view set out in the 2030 Sustainable Development Agenda requires intensive cooperation and solidarity at all levels, and an innovative integrated system for the management of cultural, natural and environmental resources.

The culturally-focused safeguarding policy dictated by international law is therefore renewed in the light of guidelines (UNESCO 1972 and 2003 Conventions) which on the one hand intend to create agency sectors and themes, including, for example, those of

2 Moreover, safeguarding involves some systematic measures, such as: legislative framework and general policy, financial measures, implementation of local policies; fostering of interdisciplinary studies; awareness raising (at local, national and international levels, through media, seminaries, and workshops), promotion and accessibility (projects, activities, educational and information programmes and capacitybuilding).

3 See: Ethical Principles of the UNESCO 2003 Convention (Decision 10.COM 15.a). Available at: https://ich.unesco.org/en/ethics-and-ich-00866 (accessed: 12.12.2020).

4 UNO 2030 Agenda for Sustainable Development. Available at: https://www.un.org/ga/search/ view_doc.asp?symbol=A/RES/70/1\&Lang=E (accessed: 21.08 .2020$)$. 
cultural heritage, creativity and urban re-development, which are increasingly online and taken as catalysts of interaction and enhancement processes ${ }^{5}$; on the other, they rethink public policy as the right to free expression and fruition, also diversifying in this sense the relationship between cultural offerings through the multiplication of cultural contents and their consumption.

This last area brings out an even more widespread reflection that has been one of the fundamental principles of the UN mission since its origins, that is, the respect and achievement of what are defined as fundamental human rights, to which there are recurring references in the preambles of the UNESCO Conventions involved in the field of culture.

Pursuant to article 22 of the Universal Declaration of Human Rights, in fact, each individual, as a member of society, has the right to social security, as well as to realization through national effort and international cooperation and in relationship with the organization and the resources of each State, of the economic, social and cultural rights that are indispensable to its dignity and to the free development of its personality 6 .

In turn, the International Covenant on Economic, Social and Cultural Rights, adopted by the UN General Assembly on December 26, 1965 and the International Covenant on Civil and Political Rights of 1966 recognize the cultural rights of individuals and protect cultural diversity. Among the approximately thirty treaties approved by the Organization in over half a century, the following can be mentioned: the two Conventions on Copyright of 6 September 1952 and 24 July 1971; the Convention for the Protection of Cultural Property in the Event of Armed Conflict of May 14, 1954, with the Additional Protocols of 1954 and 1999; the Convention on the Illicit Trafficking of Cultural Property of November 14, 1970; the Convention for the Protection of World Heritage of November 16, 1972, shared and applied universally; the Convention for the Safeguarding of Intangible Cultural Heritage (April $20,2003)$, whose preamble explicitly refers to the Universal Declaration of Human Rights and the Pacts, and finally the Convention for the Protection and Promotion of the diversity of cultural expressions of 20 October 2005.

Almost all of the international Conventions mentioned so far have been ratified by Italy, which is a Party, having shared its statutes and purposes, both of the UN's mandate and UNESCO's mission. It is therefore a matter of being able to advance in the legal and administrative discipline by questioning the inter-relationships of the cultural heritage sectors and their collective social dimension in generating values, social meanings and at the same time users ${ }^{7}$. In this regard, in fact, the complexity of the interconnections between legal instruments and the "cultural dimension" has increasingly emerged within international debate and in the work of the World Intellectual Property Organization (WIPO), which has, since 2001, been exploring the possible conditions for protecting "Traditional Knolwedge (TK), Traditional Cultural Expressions (TCEs) and Genetic Resources (GRs)", which are generally defined as a whole as "a living body of knowledge passed from gen-

5 See Cultural heritage: a cross-cutting theme to Horizon 2020: Horizon 2020 Work Programme 2018-2020. P.70. Available at: https://ec.europa.eu/research/participants/data/ref/h2020/wp/20182020/main/h2020-wp1820-cc-activities_en.pdf (accessed: 13.07.2021).

6 In Italian legislation, for example, cultural freedoms are reconnected to the right to education, freedom of teaching, the protection of historical and artistic heritage and the landscape and the promotion of culture as well as the protection of language, freedom of religion, of opinion and expression, are recognized as intangible and inalienable and have received, in Italy with the Republican Constitution of 1948 dignity and constitutional importance, with the relative system of guarantees. For a reflection on the evolution of the concept of "Cultural Rights" in the Italian legal system see: Carcione M. From the recognition of cultural rights in the Italian legal system to the enjoyment of cultural heritage as a fundamental right // Aedon. 2013. No. 2. Available at: http://www.aedon.mulino.it/archivio/2013/2/carcione.htm.

7 In relation to this, it seems relevant to note the works of the WIPO Intergovernmental Committee on Intellectual Property and Genetic Resources, Traditional Knowledge and Folklore. Available at: https:// www.wipo.int/tk/en/igc (accessed: 21.08.2020). 
eration to generation within a community... often form[ing] part of a people's cultural and spiritual identity"8.

Starting from the 40th session of the "Intergovernmental Committee on Intellectual Property and Genetic Resources, Traditional Knowledge and Folklore (IGC)" (2019), a possible connection with the "access and benefit-sharing systems" and the analysis of some domains of the "Traditional Cultural Expressions" has emerged as a focus for reflection and analysis. The related discussion paper ${ }^{9}$ identified the four key areas for further reflection as:

- traditional cultural expressions in action (encompassing dances, plays, ceremonies, rituals, games and traditional sports, as well as other performances);

- material traditional cultural expressions (including such items as expressions of art, handicrafts, ceremonial masks or dress, handmade carpets, and architecture);

- music and sound traditional cultural expressions (before the $20^{\text {th }}$ century, most of folk songs and other genres were transmitted orally, but nowadays they are also embodied in recordings);

- verbal and written traditional cultural expressions (which may take the form of epics, legends, poetry, riddles and other narratives).

On the basis of the "Proposal for a study by the WIPO Secretariat on existing sui generis systems for the protection of traditional knowledge in WIPO Member States"10, WIPO has created the "Compilation of Information on National and Regional Sui Generis Regimes for the Intellectual Property Protection of Traditional Knowledge and Traditional Cultural Expressions"11, in which the term "Sui generis Regimes"12 is defined "as existing legal mechanisms which provide indigenous peoples and local communities (IPLCs) and other beneficiaries with intellectual property (IP) or IP-similar protection against misuse and/ or misappropriation of their traditional knowledge (TK) and/or traditional cultural expressions (TCEs), and/or distorting or culturally offensive uses" ${ }^{13}$.

8 Compilation of Information on National and Regional Sui Generis Regimes for the Intellectual Property Protection of Traditional Knowledge and Traditional Cultural Expressions // WIPO. 07.05.2020. Available at: https://www.wipo.int/export/sites/www/tk/en/resources/pdf/compilation_sui_generis_regimes. pdf (accessed: 21.08.2020).

9 WIPO Intergovernmental Committee on Intellectual Property and Genetic Resources, Traditional Knowledge and Folklore. Traditional Cultural Expressions: A Discussion Paper. WIPO/GRTKF/IC/40/13. Fortieth Session 17-21.06.2019.

10 WIPO Intergovernmental Committee on Intellectual Property and Genetic Resources, Traditional Knowledge and Folklore. Proposal for a Study by the WIPO Secretariat on Existing Sui Generis Systems for the Protection of Traditional Knowledge in WIPO Member States. WIPO/GRTKF/IC/40/14. Fortieth Session 17-21.06.2019.

11 Compilation of Information on National and Regional Sui Generis Regimes...

12 The category of "sui generis" law is widely debated — and applied — in Italy since 1996 according to the European Directive 96/9/CE.

13 It is possible to read in the informative compilation that "The sound working methods under the mandate are to include an evidence-based approach mentioned in paragraph (c) of the mandate, with particular reference to conducting and updating studies covering domestic legislation in paragraph (d). These tasks facing the IGC involve balancing a complex set of issues that include responding to indigenous people(s)' and local communities' concerns over the unauthorized use of TK, especially in a commercial context, while allowing active exploitation of the TK by the originating community itself and also safeguarding the interests of industry, museums, archives, libraries and other stakeholders. Over the past twenty years, a number of WIPO Members have introduced provisions into their national laws to protect TK. The IGC would benefit from a better understanding of the scope of these laws, the nature and effectiveness of their implementation, and their quantifiable impacts. This proposal aims to build upon the body of work developed in the IGC and gather further information that will provide the IGC with a better understanding of sui generis systems for protecting TK. The proposal includes questions relating to the nature of these systems, the extent to which countries have implemented and enforced such laws and regulations, examples of how 
These last themes reconnect even more insistently in the planning of global cultural policies and programs, which aim at transversal impacts of development in the territories, in the communities and in the knowledge and exchange between cultures.

As recommended in the 2030 UNO Agenda, inclusivity and sustainability are directly reflected in the economic sectors, which should work so as to reduce the inequality generated from production and consumption processes. The inequality gap arising from these processes could be reduced by increasing inclusivity and empowerment.

Based on the aforementioned observations, the process of "cultural patrimonialization" 14 proceeds through a holistic approach, which, by means of several methodologies and indicators, link the various components (social life, historical background, etc.) that build "heritage configuration" (an expression used by the author to refer to the dynamic and flexible nature of the heritage in the contemporary) from a socio-cultural perspective. The dynamic concept of patrimonialization organically advances both tangible and intangible aspects. The evidence of material culture, as a component of humanity responding to history and environment, is already contemplated in article 2 of the UNESCO Convention for the Safeguarding of the Intangible Cultural Heritage, which defines $\mathrm{ICH}$. Furthermore, the more generic concept of "cultural and natural spaces" (art. 2 of the UNESCO 2003 Convention) offers a glimpse of the wider potentialities of the promotion of "sustainable integrated safeguarding plans", which could involve ecosystems and cultural-natural landscapes.

Nevertheless, the assumption that territory (in the morphological sense) and cultural landscapes ${ }^{15}$ are not separate from the results of human activities was also recognized by the UNESCO Convention for the Protection of World Heritage (1972) ${ }^{16}$. Indeed, that Convention pointed at the Outstanding Universal Value of "living cultural tradition, traditional human settlement, land/sea-use, human interaction with the environment, up to events or living traditions, ideas, beliefs, and artistic and literary works of outstanding universal significance" 17 as well as stating clearly that the "properties may be understood to meet the conditions of authenticity if their cultural values (as recognized in the nomination criteria proposed) are truthfully and credibly expressed through a variety of attributes including: form and design; materials and substance; use and function; traditions, techniques and management systems; location and setting; language, and other forms of intangible heritage; spirit and feeling; and other internal and external factors"18.

A concrete example of the correspondence between tangible and intangible heritage can be seen in two different UNESCO nomination cases: one concerned with an inscrip-

such laws and regulations have been applied, any quantifiable or other benefits that have been derived from these laws, whether these laws would apply to subject matter used by the public, and any exceptions and limitations that may apply" (the results of consultation are available at: https://www.wipo.int/export/ sites/www/tk/en/resources/pdf/compilation_sui_generis_regimes.pdf).

14 "The term patrimonialization, primarily used in francophone studies, refers to the way that places, popular traditions and artefacts are transform into heritage. Processes involved in a complex global/local context - the cultural, historical, social, economic, juridical and political system" (Sousa F. Intangible Cultural Heritage. MEMORIAMEDIA e-Museum, methods, techniques and practices // Memória Imaterial. 2015. CRL. P.6. Available at: https://www.researchgate.net/publication/333193967_INTANGIBLE_CULTURAL_HERITAGE_MEMORIAMEDIA_e-Museum (accessed: 21.08.2020).

15 The meaning of "cultural landscape" included in the UNESCO Convention for the Protection of World Heritage (1972) dates back to the 1990s. "Cultural landscapes" are defined at Section II. A "Definition of World Heritage", article 47 of the Operational Guidelines for the Implementation of the World Heritage Convention (2019).

16 Official text is available on the UNESCO website at: https://whc.unesco.org/en/conventiontext (accessed: 21.08.2020).

17 Operational Guidelines for the Implementation of the World Heritage Convention. 2019. No. 77 criteria V and VI // UNESCO. Available at: https://whc.unesco.org/en/guidelines (accessed: 21.08.2020).

18 Ibid. No. 82. 
tion in the World Heritage List, and the other regarding the Representative List of intangible cultural heritage.

The Vineyard Landscape of Piedmont: Langhe-Roero and Monferrato ${ }^{19}$, is an Italian property which has already been inscribed in the World Heritage List, under the category of "cultural landscapes" in adherence with the following criteria:

- The vineyard landscape of Langhe-Roero and Monferrato is the extraordinary result of a "wine tradition" that has evolved and has been passed down from ancient times until today and constitutes the basis for the area's social and economic structure. This cultural tradition is evident in a consolidated heritage of cultivation and winemaking expertise and techniques that are based on a thorough understanding of the grape varieties cultivated there over many years and their ability to adapt to particular environmental conditions. This wealth of knowledge has continued to evolve through constant efforts to improve the production cycle while maintaining traditional methods and has led to the production of high quality wines of international prestige. The thousand-year tradition of winemaking is visible in the layout of the landscape, a palimpsest of places where grape growing and winemaking take place, places featuring vineyards, divided up into small plots created in the Middle Ages by feudal land division $\langle\ldots\rangle$.

- Furthermore, the vineyard landscape of Langhe-Roero and Monferrato is an extraordinary example of the interaction between society and the environment, a constant relationship that has gone on for two thousand years. Over the centuries, vineyards, settlements and social forms of life learned to integrate, creating a living landscape where every transformation is the result of Man's determination to make the most of form, content and function for the purposes of grape growing and winemaking $\langle\ldots\rangle^{20}$.

From a living heritage perspective, an emblematic element is the Celebration of Celestinian Forgiveness, which was recognized under the UNESCO 2003 Convention. This element is defined as: "a traditional celebration inspired by Pope Celestine V, who issued a historical 'Bull' as an act of partnership among local populations. It is an intangible cultural heritage, a set of rituals and celebrations passed down uninterruptedly since 1294 conveying a strong sense of continuity and cultural identity for the whole community" 21 .

During 2009 L'Aquila City was hit by a severe earthquake that destroyed the old city, a large part of which is still inaccessible, and caused the death of some 300 people. Significantly, the community decided not to stop the annual celebration, thus leveraging $\mathrm{ICH}$ values to compensate for the partial loss/lack of tangible heritage (a vast part of the Basilica of Collemaggio was damaged as well). This social resilience within civil society allowed a group of bearers and practitioners (Associazione Comitato Perdonanza Celestiniana) to

19 Vineyard Landscape of Piedmont: Langhe-Roero and Monferrato // UNESCO. Available at: https:// whc.unesco.org/en/list/1390 (accessed: 21.08.2020).

20 The Vineyard Landscape of Piedmont: Langhe-Roero and Monferrato: Executive Summary. 2014. P. 10 // UNESCO. Available at: https://whc.unesco.org/uploads/nominations/1390rev.pdf (accessed: 21.08.2020).

21 "The lighting of the 'Fire of Morrone' and its descent from the Hermitage of Celestine V near Sulmona accompanied by a candlelight procession open the 'Forgiveness Walk' along a traditional itinerary marked by the lighting of tripods in each of the 23 villages involved and the signature by each mayor of a parchment recalling the Bull's symbolic values. The community gathering ends up on August 23rd in L'Aquila with the lighting of the last tripod, which keeps burning until August 29th. Anticipated by 1000 people of the civil society, drums, clarions and flag bearers enliven and mark the rhythm of the 'Parade', made up of 1000 citizens wearing traditional costumes, walking along with the three main characters, the 'Lady of the Bull', the 'Young Lord' and the 'Lady of the Cross', symbolizing the Celebration traditional values: hospitality, solidarity and peace. The city Mayor reading of the historical Bull anticipates the opening of the Basilica of Collemaggio Holy Door and its ritual crossing (first historical Jubilee event). The Celebration ends on August 29th: the Holy Door is closed, the Parade walks the Bull back to the Municipal Hall, the tripod flame is extinguished" (Celestinian forgiveness celebration // UNESCO. Available at: https://ich. unesco.org/en/RL/celestinian-forgiveness-celebration-01276 (accessed: 21.08.2020)). 
work towards the UNESCO nomination process for the ICH Representative List, resulting in the inscription of this cultural heritage on that list in 2019. Moreover, the Basilica of Collemaggio was restored in a timely manner (in 2017) thanks to the leading interdisciplinary coordination of the "Superintendency for Archaeological, Artistic and Architectural Heritage and Landscape for L'Aquila and its Seismic Crater" (acting under the Italian Ministry for Cultural Heritage and Activities and for Tourism ${ }^{22}$. Such a timely and effective intervention provides an exemplary evidence, and a model of a post-disaster restoration and conservation, underlined by Europa Nostra as follows: "This intervention truly represents the rebirth of a city, the strong sense of spirituality and the participation of the community in this project must be considered as an integral piece of the whole $<\ldots>$ "23.

The aforementioned two examples well express, from different perspectives, the relationship between the tangible and intangible in terms of safeguarding, promotion, and accessibility. Indeed, living practices shape anthropomorphic territories and spaces, and the inherited knowledge and manifestations dynamically become part of the "habitus" 24 of people, of their sites, their public areas, the urban/rural-shaping and fruition they enact.

Beyond the above examples, it is worth distinguishing some heritage paradigms and criteria, both at national and international levels, in light of the UNESCO Conventions (1972 and 2003) in the field of Culture ${ }^{25}$. While the concept of "World Heritage Property" (under the 1972 Convention) is based on the principles of integrity and authenticity as additional requirements to the Outstanding Universal Value, the Intangible Cultural Heritage (ICH) of the 2003 Convention stands out for being inclusive, traditional, living, and community-based. If the identification of "World Heritage Property" implies the definition of its geographical coordinates, as well as of their boundaries and buffer-zones, ICH refers to a wider localization context, according to criteria of community-inclusivity and "cultural affinities" among elements as a UNESCO publication clarifies: "We may share expressions of intangible cultural heritage that are similar to those practised by others. Whether they are from the neighbouring village, from a city on the opposite side of the world, or have been adapted by peoples who have migrated and settled in a different region, they all are intangible cultural heritage: they have been passed from one generation to another, have evolved in response to their environments and they contribute to giving us a sense of identity and continuity, providing a link from our past, through the present, and into our future. Intangible cultural heritage does not give rise to questions of whether or not certain practices are specific to a culture. It contributes to social cohesion, encouraging a sense of identity and responsibility which helps individuals to feel part of one or different communities and to feel part of society at large" 26 .

Moreover, whilst the main purpose of the 1972 Convention is aimed at preserving the Outstanding Universal Value and ensuring the protection of the nominated property, the fundamental prerogative of the safeguarding of $\mathrm{ICH}$ addresses both formal and nonformal transmission to future generations, as a guarantee for vitality, promotion and, in some cases, revitalization.

22 Progetto Collemaggio // Ministero per i beni e le attività culturali e del turismo. 2020. Available at: http://su-aq.beniculturali.it/index.php?it/319/progetto-collemaggio (accessed 21.08.2020).

23 Available at: http://www.europeanheritageawards.eu/winners/basilica-santa-maria-di-collemaggio (accessed: 21.08.2020).

24 Bourdieu P. Il senso pratico. Armando: Rome, 2005. P. 84.

25 It is however significant to note that within the framework of the 2003 UNESCO Convention, the thematic investigation criteria of the elements have been set up on the official website of reference, including the one that coincides with the World Heritage Sites.

26 What Is Intangible Cultural Heritage? // UNESCO. Available at: https://ich.unesco.org/en/what-isintangible-heritage-00003 (accessed: 12.12.2020). 
In line with the Italian regulatory tradition founded on the protection of tangible cultural heritage, the "Italian Code of Cultural Heritage and Landscape" (Legislative Decree 42 of 2004) recognizes intangible cultural interests ${ }^{27}$, but has not yet clearly introduced any statement about the involvement of local communities. At the same time, however, it is not negligible that the same Italian code still includes direct references to the "protection", "management" and "promotion" of cultural heritage through the recognition of the "reproduction rights" 28 related to that heritage. The application of this normative framework is found in the Civil Code (Administrative Code), industrial and intellectual property rights (Industrial Property Code) and Copyright Law ${ }^{29}$.

The conservation and protection of cultural material and landscape heritage entails the adoption of technical and disciplinary tools and specific rules, distinguished from those that require that the intangible elements should be centered on bearers and practitioners. Under the latter tools and rules, bearers and practitioners are addressed as the primary beneficiaries, materially and morally, under an ethical approach in line with the widest supranational code of the Organizations of the United Nations which have tended, since the origins of the UN, to develop a universal code of values and communication that can be shared by all, regardless of cultural diversity: in that sense, one of the main ongoing debates is around "individual and collective rights" corresponding to practices, manifestations and expressions of heritage-communities.

Specifically, the UNESCO 2003 Convention mentions "the diversity of issues linked to protection of various rights of the communities, groups and individuals, connected to the safeguarding of the $\mathrm{ICH}^{30}$ and the "application of intellectual property rights, privacy rights and any other appropriate forms of legal protection, to ensure the rights of the communities, groups and individuals that create, bear and transmit their intangible cultural heritage are duly protected when raising awareness about their heritage or engaging in commercial activities" 31 . In the meantime, the Operational Directives of the 2003 Convention require the States Parties to take care to ensure that awareness-raising activities will not de-contextualize or denaturalize ICH. Furthermore, under the Operational Directives, States Parties must seek to prevent the misappropriation or abuse of the knowledge and skills of bearers and practitioners, by avoiding the risks of over commercialization and unsustainable tourism ${ }^{32}$.

The strategic value of "integrated living sustainability" (an expression used by the author to mean that every heritage, both as tangible or intangible, to be sustainable needed to be living in terms of polyhedric and interfaced way. It is heritage in a socially responsive sense) is thus fully supported by the importance of $\mathrm{ICH}$ restitution and representation, including its ethical brand-making, at different levels (local national, and international). In fact, the plan and adoption of interconnected actions, which encompass all forms of social and cultural expressions - tangibility and intangibility — are still recommended as an integral part of global public policies. Even the latest re-thinking of urban measures ${ }^{33}$ not only underlines three-dimensional sustainable integration (social, economic and environ-

27 Art. 7-bis of the "Italian Code of Cultural Heritage and Landscape" (Legislative Decree 42 of 2004 and ss. m. i) introduced the direct mention at the application of UNESCO 2003 and 2005 Conventions.

28 Art. 108 of the Italian Code the "Italian Code of Cultural Heritage and Landscape" (Legislative Decree 42 of 2004 and ss. m. i).

29 In Italy the copyright jurisdiction mainly refers to the Law of 22 April 1941, No. 633.

30 Operational Directives for the Implementation of the Convention for the Safeguarding of the Intangible Cultural Heritage. 2018. No. 173.a // UNESCO. Available at: https://ich.unesco.org/doc/src/ICHOperational_Directives-7.GA-PDF-EN.pdf (accessed: 21.08.2020).

31 Ibid. No. 173.b. On the same issue, see Operational Directive No. 104.

32 Ibid. No. 102.

33 UNO New Urban Agenda. 2016. Available at: http://habitat3.org/wp-content/uploads/NUA-English.pdf (accessed: 21.08.2020). 
mental) and the urban-rural linkages, but also expressly introduces both natural and cultural heritage, as well as tangible and intangible heritage, as components of a potentially transformative process of development, also accounting for age- and gender-responsive approaches.

In the current framework, the paradigm of a "collaborative commons" 34 increasingly takes on consistency, also characterized by the progressive affirmation of a more empathic and sustainable economy, involving different stakeholders and individuals. Through global networks and the theme of "innovation" based on social and relational contexts 35 it would be possible to rethink the system of values of the cultural chain - also by strengthening the reflection on the application of benefit-sharing - that integrates tangible and intangible heritage, tradition and creativity, centers and suburbs, and balances individual and/or collective rights with those connected to the public domain, as well as promoting constant dialogue between local and international levels.

\title{
References
}

Bourdieu, Pierre. 2005. II senso pratico. Armando, Rome.

Carcione, Massimo. 2013. From the recognition of cultural rights in the Italian legal system to the enjoyment of cultural heritage as a fundamental right. Aedon, no. 2. Available at: http://www. aedon.mulino.it/archivio/2013/2/carcione.htm (accessed: 12.12.2020).

Rifkin, Jeremy. 2014. The Zero Marginal Cost Society: The Internet of Things, the Collaborative Commons, and the Eclipse of Capitalism. New York, St. Martins Press.

Schumpeter, Joseph. 2002. Theory of economic development. Milan, ETAS.

Sousa, Filomena. 2015. Intangible Cultural Heritage. MEMORIAMEDIA e-Museum, methods, techniques and practices. Memória Imaterial CRL. Available at: https://www.researchgate.net/ publication/333193967_INTANGIBLE_CULTURAL_HERITAGE_MEMORIAMEDIA_e-Museum (accessed: 21.08.2020).

Received: August 28, 2020

Accepted: January 12, 2021

\section{Материальное и нематериальное культурное наследие ЮНЕСКО: перспективы устойчивого развития}

\author{
Е. Синибальди, А. Паренте
}

Для цитирования: Sinibaldi, Elena, Parente, Antonio. UNESCO's tangible and intangible cultural heritage: Sustainable development perspectives // Правоведение. 2020. Т.64, № 1. С.47-56. https://doi.org/10.21638/spbu25.2020.104

Конвенция ЮНЕСКО об охране нематериального культурного наследия 2003 г. не только расширила на концептуальном и прикладном уровнях количество междисциплинарных тем, относимых к проблематике культурного наследия, но и еще больше поощрила комплексное планирование политики устойчивого развития территорий и общин. Эти

${ }^{34}$ Rifkin J. The Zero Marginal Cost Society: The Internet of Things, the Collaborative Commons, and the Eclipse of Capitalism. New York: St. Martins Press, 2014.

35 Schumpeter J. Theory of economic development. Milan: ETAS, 2002. Translation of the sixth German edition (1964), also on the basis of the English edition of 1934, of Theorie der wirtschaftlichen Entwicklung, 1911. According to J. Schumpter the concept of growth is to be understood as a gradual phenomenon, made up of continuous adjustments; the concept of development, on the other hand, is to be understood as a discontinuous phenomenon and is characterized by the introduction of new combinations, which may concern five dimensions: creation of products; introduction of production methods; opening of markets; discovery of sources of supply of raw or semi-finished products; reorganization of an industry. 
субъекты формируют и транслируют их относительную культурную и антропоморфную идентичность, наряду с переосмыслением упомянутого наследия с точки зрения прав на его созидание и на его плоды и связанного с таким переосмыслением управления культурой. Авторы настаивают на возможности выявления и развития взаимосвязи между материальным и нематериальным наследием как однопорядковыми ресурсами, существенными друг для друга. В качестве иллюстрации рассматриваются два пути применения Конвенции ЮНЕСКО. Первый касается признания «Виноградного ландшафта Пьемонта: Ланге, Роэро и Монферрато» культурным ландшафтом Всемирного наследия в соответствии с Конвенцией ЮНЕСКО об охране всемирного культурного и природного наследия 1972 г., а второй - включения нематериального элемента «Празднование Целестинского прощения» в репрезентативный список Нематериального культурного наследия человечества Конвенции ЮНЕСКО 2003 г. Из-за различий в тех парадигмах и критериях применения тематических исследований в рамках двух конвенций ЮНЕСКО, которые также обнаруживаются в итальянском нормативном контексте, указанные исследования дают возможность продолжить междисциплинарный диалог, направленный на переосмысление контекстов охраны различных видов культурного наследия, а также расширение и повышение его доступности. На основе такой рефлексии авторы формулируют концепцию жизни, связанную с антропологическим определением понятий органического ландшафта, репрезентации коллективной идентичности (общинное наследие), инклюзивных мест и социальности (государственная политика), коммуникативной реституции (универсальные этические ценности), партисипативного управления (партисипативное создание бренда) и интегрированной устойчивости.

Ключевые слова: ЮНЕСКО, материальное культурное наследие, нематериальное культурное наследие, устойчивое развитие, культурные коллективные права, совместное использование выгод.

Статья поступила в редакцию: 28 августа 2020 г. Рекомендована в печать: 12 января 2021 г.

Синибальди Елена - PhD, Министерство культурного наследия, культурной деятельности и туризма Италии, Италия, 00186, Рим, ул. дель Колледжио Романо, 27; elena.sinibaldi@beniculturali.it

Паренте Антонио - д-р юрид. наук, юрист, Министерство культурного наследия, культурной деятельности и туризма Италии, 00186, Рим, ул. дель Колледжио Романо, 27;

antonio.parente@beniculturali.it 